\title{
La expresión del malestar en Chile: cultura, esfera pública y luchas sociales
}

\author{
The expression of discontent in Chile: \\ culture, public sphere, and social struggles
}

\author{
Nicolás del Valle Orellana \\ International Institute for Philosophy and Social Studies, Chile \\ ndelvalle@iipss.com
}

\begin{abstract}
Resumen
Este artículo desarrolla los conceptos de esfera pública, malestar cultural y sufrimiento social en la teoría crítica para pensar en las luchas sociales como formas de protesta social y contestación política ocurridas desde octubre de 2019 en Chile. El artículo explora la tesis sobre el descontento social, que sostiene que las luchas sociales recientes son una expresión pública del malestar cultivado por los procesos de modernización social. Según el autor, más allá de la justificación normativa en razones y argumentos sobre las condiciones de injusticia que afectan a los agentes en lucha, la crítica social emerge del sufrimiento social que encuentra su lugar en la materialidad de los discursos, las imágenes y los cuerpos en la esfera pública.
\end{abstract}

Palabras claves: teoría crítica, sufrimiento social, descontento, cultura, crítica social.

\begin{abstract}
This article develops the concepts of the public sphere, cultural malaise and social suffering in critical theory to think of social struggles as forms of social protest and political protest that occurred since October 2019 in Chile. The article explores the thesis on social discontent, which maintains that recent social struggles are a public expression of the unrest cultivated by processes of social modernization. According to the author, beyond the normative justification in reasons and arguments
\end{abstract}

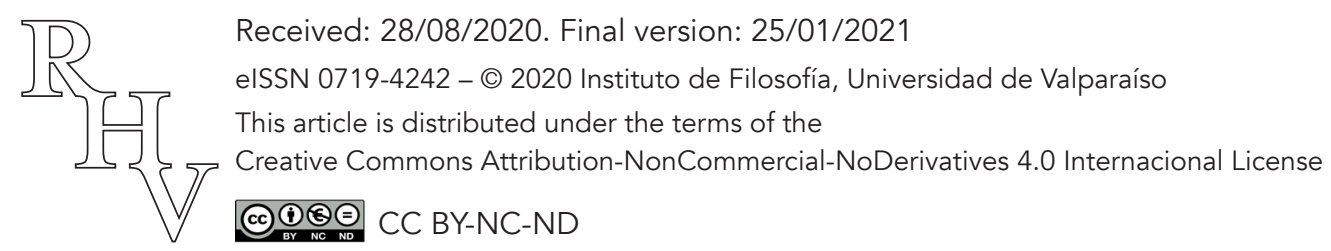


La expresión del malestar en Chile: cultura, esfera pública y luchas sociales

Nicolás del Valle Orellana

regarding the conditions of injustice that affect the agents in struggle, the social critique emerges from the social suffering that finds its place in the materiality of the discourses, images and bodies in the public sphere.

Keywords: critical theory, social suffering, discontent, culture, social criticism.

\section{Introducción}

¿Qué experimentamos cuando atendemos a un acontecimiento histórico como el de una manifestación social pública, masiva y mayoritaria que cuestiona el orden social y político vigente? ¿Cómo se constituyen estas experiencias que muchas veces desencadenan un proceso de transformación política? Los acontecimientos históricos se atesoran en las memorias culturales y en las historias oficiales de los pueblos, son transmitidos a lo largo de generaciones a través de palabras, imágenes y prácticas concretas. Con ellas, estos acontecimientos devienen experiencias sociales al participar de un proceso colectivo de comparecencia, de contacto en una esfera común en y a través de la cultura. Los nombres de las luchas sociales en la historia del pensamiento político han sido muchos. Han sido bautizadas por "protestas", "insurrecciones", "revueltas", "rebeliones" y "revoluciones", pero también como "ejercicios democráticos" de las libertades de expresión, asociación y participación política, o de desobediencia civil contra un orden ilegítimo. En cualquier caso, en este artículo se supone de entrada que los marcos categoriales de las disciplinas tradicionales de la filosofía y las ciencias sociales colapsan al no contar con conceptos y teorías que expliquen este acontecimiento. Más bien, la investigación sobre los nombres de los acontecimientos desencadenados por las luchas sociales no es tanto para encontrar un concepto que explique el fenómeno en su totalidad, sino para desentrañar los diferentes modos y formas del conflicto social que afectan y condicionan la comprensión histórica por medio de la producción y circulación de discursos sobre el acontecimiento del cual quiere darse cuenta.

En el caso del así llamado "estallido social" de octubre de 2019 en Chile se puede constatar lo antes dicho, esto es, una manifestación popular en la esfera pública que cuestionó de manera radical el orden social y político imperante en la sociedad, desencadenando un proceso de transformación constitucional. Pensar luchas sociales no es sino habitar el conflicto, atender a la posición que tenemos frente a ellas como pensadores, esto es, caer en cuenta que la comprensión crítica de lo social refiere a la condición intelectual del propio ejercicio de la investigación. En mi caso, si bien este artículo no se centra en un análisis empírico de las luchas sociales en Chile, sí se sitúa como una reflexión que emerge desde la experiencia en la esfera pública del país. Siguiendo esta idea, el pensamiento sobre el conflicto social que se ensaya en este artículo está situado en la contingencia, pero también apunta fuera de los límites de la coyuntura y así aspira a delinear orientaciones conceptuales para el debate público desde una reflexión teórica y crítica. El presente escrito no puede considerarse como un ejercicio teórico fuera de la situación, desencajado de las

Revista de Humanidades de Valparaíso, 2021, No 17, 63-89

(c) $(1)(9)$ CC BY-NC-ND 
La expresión del malestar en Chile: cultura, esfera pública y luchas sociales

Nicolás del Valle Orellana

condiciones históricas desde las cuales las luchas sociales se despliegan, pero tampoco es un artículo que contraste sus hipótesis con la vida social o compruebe sus postulados. Se trata de un escrito teórico que intenta volver sobre ciertas cuestiones conceptuales que pueden contribuir a esclarecer el debate intelectual y político, suponiendo que es posible pensar la conexión entre la teoría crítica y la crítica social, es decir, desde la teoría crítica hacia las prácticas de protesta y contestación en la esfera pública.

Este escrito intenta de hacerse cargo de un debate teórico respecto de cómo comprender críticamente los acontecimientos políticos caracterizados por la protesta social y la contestación política de las luchas sociales. Por ello, se profundizará en algunos conceptos y argumentos que me parecen relevantes para la teoría de las luchas sociales en términos generales, pero también respecto de la propia experiencia que significó el "estallido social" y las hipótesis de lectura que han acompañado el proceso social de transformación asociadas a las tesis del malestar social resultante del proceso de modernización capitalista. La comprensión de las relaciones sociales que se juega en dichos momentos radica en sus despliegues históricos, en las diferentes formas de crítica social que promueven un cambio político y de las racionalidades de gobierno orientadas a la conservación del orden social. El presente artículo aspira a discutir algunas reflexiones teóricas generales que presenten el argumento sin caer en la discusión concreta del debate público, aun cuando se incluye una consideración metodológica respecto del caso de octubre en Chile para situar la pertinencia de la discusión conceptual. Me preguntaré por los conceptos, pero sin por ello desatender sus tensiones con la realidad desde la cual se piensa. Para cumplir con esta aspiración, el primer apartado sirve de situación crítica respecto del acontecimiento político que significa las revueltas sociales de Octubre de 2019 a partir de la discusión intelectual a nivel nacional, lo cual permitirá demostrar la pertinencia de preguntarse por la relación entre malestar social y esfera pública para pensar las luchas sociales.

Me parece que para abordar críticamente las protestas sociales, hay que constatar que corresponden a experiencias que se forjan colectivamente en un horizonte delineado por la "esfera pública", concepto ausente de las reflexiones sobre el estallido chileno. ¿Cómo sucede que una experiencia es articulada colectivamente y cobra mayor relevancia en el quehacer político de una sociedad? ¿Cuál es el horizonte que enmarca esa experiencia colectiva de las protestas que alcanzan una notoriedad inusitada? Efectivamente estos acontecimientos históricos emergen a través de una cadena de acciones que terminan constituyendo una manifestación pública del desacuerdo. Tanto revoluciones políticas como movimientos sociales han comenzado con acciones particulares sin cálculo político o planificación previa, encontrando su amplia difusión a través de los medios de comunicación, agentes que hacen un acompañamiento durante todo el proceso de conflicto social. Hechos como el asesinato de una joven mujer en manos de un ex-convicto, un ciudadano afrodescendiente asesinado por un policía, el suicidio de un pequeño comerciante por el abuso policial, la muerte a causa de la fuerza desmedida del Estado para contener las protestas, son algunos de los actos que han logrado abrir el campo de la discusión política 
La expresión del malestar en Chile: cultura, esfera pública y luchas sociales

Nicolás del Valle Orellana

para comenzar a delinear un horizonte social que desplaza una "experiencia particular del sufrimiento" a una "experiencia colectiva de descontento". Todos estos actos han podido desencadenar conflictos sociales que devienen en procesos de transformación radical de una sociedad. Estas acciones pueden esclarecer fuerzas que, hasta ese momento, se consideraban como conflictos potenciales o latentes, difusos y expandidos.

Entonces, ¿a través de qué medios y mecanismos una experiencia social es articulada y se vuelve relevante en un contexto determinado? La posibilidad de una experiencia colectiva como la señalada, consistente en la articulación y propagación masiva de una acción, es la existencia de una esfera donde los asuntos comunes son discutidos públicamente. La circulación de imágenes, discursos y cuerpos en esta esfera ocurre de acuerdo a diferentes dispositivos, como espacios y medios de comunicación tanto materiales como inmateriales. La experiencia social es, entonces, resultado de un proceso de mediación del acontecimiento histórico por la memoria cultural producida en torno a experiencias similares o distintas que se encuentran en el pasado común de una sociedad, por las creaciones artísticas y culturales, sensible e imaginativas, sobre las singularidades del presente y para el futuro. Como se sostendrá más adelante, la experiencia del acontecimiento se constituye socialmente a través de la esfera pública. Es en la esfera pública donde las luchas sociales tienen lugar, es el espacio de aparición de las demandas y desacuerdos sobre los asuntos que son comunes a quienes forman parte de la sociedad. La experiencia está mediada culturalmente, primero, por la memoria compuesta por aquellas figuraciones que olvidan, silencian o traen al presente asuntos del pasado o interpretan vivencias del presente a la luz de lo acontecido, y en segundo lugar, por las expresiones culturales y los medios que la tecnificación de la cultura y la sociedad traen consigo.

Sin profundizar ahora en este asunto, la relación entre experiencia social y esfera pública es una de los andamiajes generales de este artículo. Esta conexión es especialmente importante cuando nos referimos al análisis de la esfera pública en una sociedad heterogénea donde no existe un solo horizonte de experiencia en común, sino a lo sumo una constelación de tensiones que marcan los márgenes difusos de aquellos asuntos públicos y comunes a los miembros de una sociedad.

En este artículo se argumenta que contrario a las versiones tradicionales de la esfera pública, ésta no corresponde con un espacio política unificada a la cual todos tienen acceso y la posibilidad de expresar su propio parecer a través de argumentos razonables. Más bien, la esfera pública corresponde a un campo heterogéneo de fuerzas que constituyen un entramado de públicos que se enfrentan (o no) al orden social en su conjunto. Serían esferas públicas en plural constituidas por conflictos sociales, que a su vez son movidos por padecimientos, deseos y sufrimientos. En este sentido, las luchas sociales estarían motivadas por el malestar y no solo por una racionalidad discursiva de razones y argumentos fundados en principios abstractos de justicia. Mientras que la esfera pública ha sido dominada por élites y grupos de notables a través de razones y argumentos publicados en los medios de comunicación tradicionales, se excluyen otras prácticas políticas que

Revista de Humanidades de Valparaíso, 2021, No 17, 63-89

(c) $(i) \Theta(9)$ CC BY-NC-ND 
La expresión del malestar en Chile: cultura, esfera pública y luchas sociales

Nicolás del Valle Orellana

configuran el complejo de las esferas públicas como una extensión de las relaciones de fuerza. Incluso con Nietzsche ya podríamos decir que detrás del intercambio razonado de argumentos se encuentra la voluntad de poder, esto es la simple y bruta relación de poder.

Volviendo al caso chileno, cabría decir que el denominado "estallido social" es la expresión en la esfera pública de un malestar forjado durante años de modernización social. Esta expresión del malestar significó el despliegue de un conjunto de prácticas de protesta y contestación en el espacio público de tipo artístico y cultural, que juegan en el campo de la imaginación popular y no en la del cálculo tecnocrático. El artículo sostiene que las luchas sociales pueden ser comprendidas como despliegues de fuerzas a través de un amplio repertorio de prácticas disidentes que responden a dimensiones sociales y culturales del malestar, pero también a disposiciones institucionales de la esfera pública como espacio de aparición política que facilita la discusión sobre los asuntos comunes. Con ello se sostiene que el malestar se expresa en la esfera pública, haciendo de ésta un dispositivo democrático para la crítica social. Las luchas son el ejercicio práctico de la crítica social como una política democrática radical que se constata en las demostraciones en las calles (Butler 2015). Esta política de la calle tiene sus particularidades pues no hay una voluntad unificada detrás, ni tampoco proyecto o cálculo político; es más bien el despliegue en alianza de los cuerpos, discursos e imágenes de manera estratégica contra las figuras y símbolos que componen el orden social y político. Estas manifestaciones del malestar encuentran en el arte y la cultura su lengua de expresión, siendo el carácter performativo de la protesta, la capacidad expresiva del sufrimiento acumulado durante los años de modernización capitalista.

La pregunta que la teoría crítica se ha hecho sobre las motivaciones de las luchas sociales queda en entredicho. Siguiendo el ímpetu negativo de la teoría crítica, las nociones de sufrimiento y malestar acompañan los conceptos de la alienación (Jaeggi 2014), de desagravio (Honneth 2007) y de explotación (Marx 1993) que caracteriza a la teoría crítica contemporánea. Pero, a diferencia de cierta deriva de interpretación de la Escuela de Fráncfort que centra la motivación de las luchas sociales en los argumentos fundados sobre las justificaciones del orden social (Forst 2012; 2015), este escrito plantea una clave de lectura alternativa que se enfoca en la materialidad del sufrimiento de los cuerpos que se forja durante el proceso civilizador del progreso social. Considerando la importancia del psicoanálisis de Freud en los análisis de la cultura, la noción de malestar nos abre a los diferentes modos de lidiar con el sufrimiento. Aquí, Adorno (1970) apunta a las artes y la memoria cultural como lenguas del sufrimiento a través de la protesta. Habrá que preguntarse entonces por dichas prácticas políticas, en torno a la producción de un valor social en la esfera pública, a través del uso de los cuerpos, los discursos y las imágenes. Deteniéndome especialmente en Habermas, Adorno y Freud, este artículo corresponde a un simple esbozo conceptual, pero para llegar a ellos, deberemos explorar la pertinencia de dichos conceptos. 
La expresión del malestar en Chile: cultura, esfera pública y luchas sociales

Nicolás del Valle Orellana

\section{La experiencia del estallido social}

El testimonio es quizás uno de los recursos más relevantes de las ciencias sociales pues responde a la dimensión de la experiencia subjetiva de quienes participan, presencian y comparecen un mismo acontecimiento histórico. Este artículo no es un testimonio, pero comienza desde la experiencia subjetiva del estallido como expresión del malestar. Esta primera experiencia desde la cual intento desarrollar algunas cuestiones conceptuales sobre la relación entre la esfera pública y el malestar en la cultura, fue ampliada con el estallido de protestas y movilizaciones, anudando aquella perspectiva individual y subjetiva con un horizonte social donde se expresa la sensibilidad de los cuerpos la materialidad del territorio. Justamente es en aquellos ensayos de corte biográfico y periodístico que encontramos esta apelación a la propia sensibilidad. En su ensayo político sobre los acontecimientos de octubre, titulado Rebelión (2020), el escritor Jorge Baradit narra al lector desde su experiencia personal refiriendo a lo impredecible del acontecimiento al tiempo de constatar que gran parte de la sociedad sentía lo que estaba por venir: "todos lo sentíamos como electricidad en la piel, aunque al parecer ellos no" (Baradit 2020, 13). Según Baradit, la experiencia del sufrimiento era compartido por algunos: justamente aquellos que no lo vieron venir no participaban del malestar social.

Y es que los registros producidos en torno al estallido social tienen una ineludible apelación a la experiencia subjetiva desde la escritura testimonial que apelan a la sensibilidad corporal, el movimiento en las calles y el malestar como motivador de la revuelta. Este gesto se repite en la plaga de discursos e imágenes que circulan en el espacio público, siendo constatado e interpretado por escritores y cronistas: "Desde el 18 de octubre, el día de la detonación, recorro las calles como uno más, perdido entre la multitud (...) con el fin de registrar lo que sucede a su alrededor: las iras y los deseos que iluminan, las frustraciones y fracasos que queman" (Fernández 2020, 16). En las calles se podía "sentir" cierta intensidad de un malestar que llevaba años gestándose. Que los medios de comunicación, periodistas y líderes de opinión bautizaron acontecimiento como "estallido" justamente refiere a la expulsión de una gran fuerza acumulada: "No es un movimiento reivindicativo. Es una energía. Es una pulsión” (Matamala 2019, 22). Esta suposición respecto del nombre dado al acontecimiento puede ser constatada, de hecho, por aquellas tesis con pretensión de universalidad como aquellas lecturas desde la teoría social y política (Herrera 2019; Mayol 2019; Peña 2020). ¿Cuál es la relación entre estas experiencias subjetivas del acontecimiento y aquellas tesis teóricas sobre los procesos sociales y políticos? Me parece que la respuesta yace en el concepto de la esfera pública. Los diferentes escritos entre sí suponen sus condiciones de posibilidad, esto está, una industria editorial que editó los libros, medios de comunicación digital donde se difundieron los mensajes, calles y monumentos dispuestos para la contienda social y política. Incluso allí donde encontramos propuestas con aspiraciones de imparcialidad hay una toma de posición respecto del acontecimiento que solo es posible por la esfera pública, porque su estructuración

Revista de Humanidades de Valparaíso, 2021, No 17, 63-89

(c) $(1)(9)$ CC BY-NC-ND 
La expresión del malestar en Chile: cultura, esfera pública y luchas sociales

Nicolás del Valle Orellana

conflictiva afecta a la teoría, pero también porque es la esfera de lo público la que anuda las diferentes experiencias en un fenómeno mayor de configuración de una experiencia colectiva del malestar.

Sostengo que las interpretaciones que compiten en la esfera pública por la comprensión del acontecimiento y el proceso iniciado en Chile, suponen un marco conceptual que refiere al malestar y su relación con el progreso social, en las más diversas variantes de la modernización capitalista en América Latina. Detrás de las hipótesis comprensivas que se enarbolan en el contexto nacional para explicar y analizar las relaciones sociales, podemos encontrar una concepción general que afirma que el malestar es resultado del progreso social de la sociedad chilena en la historia reciente. En algunos casos se sostiene que el malestar es el resultado de la modernidad en Chile que fue acelerada con la llegada del neoliberalismo, en otros se argumenta que se debe a un desajuste entre facticidad y validez, entre las aspiraciones de la sociedad y las condiciones histórico-materiales en las cuales nos situamos. A pesar de este ejercicio ordenador, se trata solo de un esfuerzo conceptual, pues el amplio espectro de discursos sobre el estallido, aunque pueden coincidir en la tesis del malestar, difieren en sus claves de interpretación, las cuales provienen de registros muy diversos, periodísticos e historiográficos, filosóficos y sociológicos, antropológicos y politológicos. Cuando atendemos a los textos con mayores pretensiones teóricas, en unos se asume que la modernidad es un proyecto inconcluso por definición y sobre todo en nuestra región y país. Algunos asumen que la raíz el problema no es la modernidad sino su versión neoliberal. Otros que no es el neoliberalismo, sino que todos los procesos de modernización producen malestar social y debemos lidiar con ello.

De los escritos que pudieron ser revisados para este artículo, la gran mayoría parece vérselas con lo que aquí llamamos la tesis del malestar social. A pesar de esta convergencia, una cuestión que no dejó de llamarme la atención es que todas ellas no reparaban respecto de cómo las transformaciones de la esfera pública en Chile hacían posible la expresión del malestar en las calles. A lo sumo aludían al rol de las redes sociales como nuevos modos de comunicarse. Ciertamente la digitalización de las comunicaciones es un factor ineludible si queremos comprender las luchas sociales contemporáneas, pero ésta es un efecto que responde a un proceso estructural mayor de transformación de la esfera pública como dispositivo democrático para la crítica social y política, como espacio de protesta social y contestación política. De acuerdo a esta idea, la esfera pública corresponde al espacio a través del cual se expresa el malestar en las calles. Las crisis políticas en la historia de la civilización humana han estado marcadas por revueltas, pero las revoluciones modernas y las manifestaciones sociales en el mundo contemporáneo están configuradas por la estructuración de una esfera pública gestada en los marcos del Estado nación moderno, donde la información cruza sus fronteras y donde la opinión pública es cada vez más volátil y relevante para la toma de decisiones, donde el espectáculo y la industria cultural hacen uso de las imágenes y las sonoridades en la definición del imaginario cultural.

Revista de Humanidades de Valparaíso, 2021, No 17, 63-89

(c) $(1)(9)$ CC BY-NC-ND 
La expresión del malestar en Chile: cultura, esfera pública y luchas sociales

Nicolás del Valle Orellana

\section{La tesis del malestar social en Chile}

Uno de los puntos de entrada a la tesis del malestar se encuentra en su relación con la modernización. Esta idea arranca de una pregunta capital de la sociología en América Latina respecto de las tensiones entre cultura y modernización, donde la obra de Pedro Morandé (2017) abre una perspectiva crítica respecto de los procesos de modernización en la región que olvidan las particularidades culturales e históricas desde las cuales se podría reformular un proyecto de desarrollo no frustrado. La modernización corresponde a ese proceso de racionalización social conlleva una progresiva diferenciación funcional de la estructura de la sociedad y un aumento de la complejidad de los sistemas sociales. Esta referencia a la sociología de la modernización, que se encuentra en la larga historia de la teoría sociológica que va desde la teoría de la racionalización social de Max Weber hasta la de los sistemas sociales complejos de Niklas Luhmann, es un punto ineludible para la tesis del malestar social. En el caso de la teoría crítica, uno de los textos fundadores de la tradición es la Crítica de la razón instrumental (2010) de Max Horkheimer.

Aludiendo a esta basta tradición y a sus autores en América Latina, en su texto Pensar el malestar. La crisis de octubre y la cuestión constitucional (2020), Carlos Peña sostiene que "todos ellos coinciden en que la esfera de la cultura o de la subjetividad de los individuos va despegada, en principio, de la racionalización de los procesos sociales, lo que genera una sensación de alienación o ajenidad que alimenta, es probable, otros procesos. Entre ellos, claro está, el malestar" (Peña 2020, 118). Esta idea, que ya se encontraba en autores de tradiciones disímiles. Georg Lukács, Walter Benjamin y Theodor W Adorno desde la izquierda, o como Ernest Jünger, Carl Schmitt y Martin Heidegger desde la derecha, vuelve a cumplir un papel en la tesis del malestar social en Chile.

Sin detenernos en los diferentes momentos iniciales del debate sobre el malestar social en Chile, los cuales han sido desarrollados en otros lugares (Del Valle et. al. 2018), resulta revelador revisar los escritos sobre el estallido social, pues se destaca la existencia una lectura respecto de los vínculos entre malestar y de modernidad en Chile.

Siguiendo la lectura conservadora, en el contexto nacional es avanzada por Hugo Herrera en su texto sobre la comprensión política del acontecimiento de octubre en Chile (2019) una crítica de la razón instrumental que trata de rescatar una noción de pueblo desde la tierra dejando a la política al arte de conducir los anhelos y pasiones del pueblo para ejercer un liderazgo legítimo que promueva discursos e instituciones afines a los ánimos populares Según esta lectura, el estallido es la "expresión masiva" de un "malestar difuso y extendido, que todos de alguna manera perciben" (Herrera 2019, 15). Esta expresión masiva tomaría forma en ciertos símbolos de la modernidad en Chile que encarnan "tensiones y paradojas de nuestra modernidad" (Herrera 2019). La paradoja consiste en el proceso de socialización de una racionalidad económica entrañaba al avance técnico por sobre la relación con la tierra y la naturaleza, negando las pulsiones y características propias del pueblo en su territorio:

Revista de Humanidades de Valparaíso, 2021, No 17, 63-89

(c) $(1)(9)$ CC BY-NC-ND 
La expresión del malestar en Chile: cultura, esfera pública y luchas sociales

Nicolás del Valle Orellana

La revuelta de octubre viene a evidenciar, con su volumen y su ímpetu, la incapacidad acumulada del sistema político y sus dirigencias de cumplir con su tarea. Las pulsiones y anhelos populares han sido reprimidos hace tiempo y a tal punto que el pueblo devino rebelde. La masividad del alzamiento y la envergadura del malestar que expresa (...) permiten sostener que la manifestación es brutalmente auténtica" (Herrera 2019, 42).

Este análisis que Herrera hace desde la filosofía política republicana - popular y telúrica, a decir del autor - está suponiendo un andamiaje conceptual entre los conceptos de malestar social y la modernización resultante de lo que él llama racionalidad liberal economicista.

En un sentido distinto, Carlos Peña también argumenta que el malestar social es en la modernización, "como si el cambio en las condiciones materiales de la existencia que ese tipo de modernización produce tuviera un revés inevitablemente amargo (...) Es la inevitable ambivalencia de la modernización." (Peña 2020, 119). Para este autor, la modernización no sería solo un proceso de mayor diferenciación y complejidad interna de la sociedad, significa también la progresiva conquista de los individuos sobre sus propias vidas, haciéndolo en Chile a través del dinero y el mercado como espacio de emancipación. Todo proceso de racionalización social implicaría una transformación radical de las condiciones materiales de existencia, mejorando la situación de la población y propiciando la emergencia de nuevas clase sociales. Con este movimiento de ascenso social se obtiene como resultado que "la modernización capitalista descansa en la ampliación de expectativas que estimulan el consumo pero, al mismo tiempo, lo amenaza la frustración" por el hiato insalvable entre los deseos de la población y las condiciones materiales (Peña 2020, 125).

El malestar surge por el progreso social que trae la modernidad, es el éxito brindado por el capitalismo que transforma la sociedad y redefine las expectativas y los parámetros normativos con los cuales los individuos evalúan las relaciones sociales y sus formas de vida. La modernización ha generado las condiciones materiales de existencia que ha tenido como su resultado la emergencia de una nueva clase media compuesta por individuos más autónomos y racionales que a través de la expansión del mercado realizan sus libertad individual. De esta situación es que se deriva una distancia entre las condiciones fácticas de la realidad y los principios y exigencias que las personas le ponen a la realidad, o en palabras del autor: "Han mejorado de una forma hasta hace poco inimaginable las condiciones materiales de existencia - hasta situarse entre los países con alto desarrollo humano - , pero al mismo tiempo ha incubado un malestar hasta hace poco soterrado y, de pronto, hecho explícito" (Peña 2020, 119). Ahora bien, esta consideración teórica general, cuando es aplicada al caso chileno, el autor sostiene que el malestar tiene como factores singulares como el recambio generacional, la crisis de legitimidad de las instituciones o la paradoja del bienestar, todas ellas enlazadas a la paradoja intrínseca a toda modernidad.

Revista de Humanidades de Valparaíso, 2021, No 17, 63-89 
La expresión del malestar en Chile: cultura, esfera pública y luchas sociales

Nicolás del Valle Orellana

Contrario a esta segunda lectura de la tesis del malestar, aparece las propuestas que asocian el malestar a la condición neoliberal de nuestra modernización reciente. De esta línea argumental, se sostiene que el malestar es con el modelo económico-político del neoliberalismo introducido con las políticas de shock implementadas desde la dictadura cívico militar de Augusto Pinochet y gestionado por los gobiernos que administraron el modelo los treinta años posteriores. El malestar sería resultado del proceso de mercantilización de la sociedad a través del consumo a través del crédito, la privatización de los bienes públicos y el debilitamiento de la institucionalidad pública. Para Mayol, el "malestar revela que las condiciones por las cuales es descrito están bastante asociadas con las características propias de las sociedades neoliberales" $(2019,143)$. No se trataría de un desafío propio de las sociedades modernas, sino una cuestión particular del modelo neoliberal. La construcción de lo social en el neoliberalismo "opera produciendo anomia y desequilibrios normativos, careciendo de capacidad de diagnóstico" (Mayol 2019, 142). Sin poder desarrollar todos los pasos de su argumento para demostrar la relación entre neoliberalismo y malestar social, Mayol concluye que "no sería cierto que el malestar está depositado en sociedades fundamentalmente desarrolladas y, además, se afirma que el malestar deriva fundamentalmente de la modernización fallida y no solo de la modernización" (Mayol 2019, 146).

Desde un punto de vista ambivalente, cabe destacar una cuarta lectura de la tesis del malestar que proviene de una teoría normativa que nace desde una crítica del orden neoliberal en Chile (Atria et al. 2014). En ella, varios de sus autores sostienen justamente que el malestar social acumulado se debe a las debilidades del orden neoliberal en cuanto a garantía de derechos universales:

¿Qué pasó en los últimos años? La respuesta corta es que "apareció el malestar" con la política, con los políticos, con todas las instituciones, con el Estado, con las empresas, con los sindicatos; un malestar generalizado. Las formas que nos parecían normales de organizar la política, la sociedad y la economía, hoy nos parecen cuestionables, aunque nos está claro ni por qué ni cuáles de esos ámbitos son realmente la causa del problema. Hasta el momento ha habido más manifestaciones de malestar que intentos de transformar ese malestar en un proyecto político (Atria et. al. 2014,4$)$

Este diagnóstico es el punto de arranque para evaluar normativamente al neoliberalismo desde el principio de lo público como un espacio de igualdad y reconocimiento que puede ser asegurado a través de ciertas garantías, derechos y libertades consagrados por los regímenes democráticos y de Estado social de derechos. Este espacio de lo público se ve severamente afectado en el orden neoliberal lo que termina por orador las bases de la legitimidad de las instituciones a la vez que genera y refuerza un malestar social. Para estos efectos, los autores proponen un "modelo de desarrollo alternativo" que puede calzar 
La expresión del malestar en Chile: cultura, esfera pública y luchas sociales

Nicolás del Valle Orellana

con otras sociedades capitalistas y modernas pero no de tipo neoliberal. En esta lectura de la tesis del malestar, las luchas sociales estarían justificadas por los principios del régimen de lo público contra las realidades del desagravio y la desigualdad de la sociedad chilena.

Cualquiera de estas lecturas de la tesis del malestar (en otras existentes) establecen una relación particular entre el desarrollo social y el malestar en la sociedad, sin embargo, ninguna de ellas de detiene en la función que cumple el surgimiento de la esfera pública en los Estados modernos. Pues los procesos de racionalización social en la modernidad también comprenden surgimiento de la sociedad civil y de la esfera pública como alternativa a la lógica del mercado como modo de coordinación y cooperación social. Para esclarecer estos puntos, en los siguientes apartados, se abordará el concepto de esfera pública en Jürgen Habermas, malestar en la cultura de Sigmund Freud y del vínculo de sufrimiento social con la cultura en Theodor W. Adorno. Supongo que algunas reflexiones generales podrán ser pertinentes para el debate ya mencionado.

\section{Esfera pública, socialización y transformación política}

Justamente las prácticas de contestación exceden aquello que usualmente se comprende como "opinión pública" y más bien podrían enmarcarse en lo que Jürgen Habermas llama la "esfera pública" (Habermas 1990). En su tesis de habilitación Transformación estructural de la esfera pública: una investigación sobre una categoría de la sociedad burguesa de 1962, Habermas estudia las condiciones sociohistóricas que posibilitaron que los individuos de la sociedad moderna en Europa pudieran participar discursiva, racional y críticamente en el espacio público, lo cual permite instalar un punto de referencia en la teoría crítica contemporánea para responder los cuestionamientos iniciales de este artículo. En aquel libro, Habermas retorna a la breve respuesta que hemos heredado de Kant a la pregunta ¿qué es la Ilustración? En su breve escrito, sostiene que la Ilustración se distingue por el uso de la razón pública como un entendimiento autónomo orientado a razonar con otros (Kant 2013). Para Habermas, en la modernidad presenciamos el auge de un nuevo espacio político y social que opera como un dispositivo de cohesión, legitimación y fiscalización social de la autoridad. Paulatinamente, con la debilidad de la censura, el surgimiento de personalidades públicas, la imprenta en la difusión de la literatura y las noticias, sumado a los nuevos salones, bares y clubes donde la discusión pública ocurría, emergieron nuevos espacios que constituyen lo que denominamos "esfera pública" y que Habermas llamaba literalmente "publicidad" [Öffentlichkeit]. Esta historia de las transformaciones estructurales de la esfera pública moderna resulta ser un proceso de largo aliento que cruza desde el siglo XIV hasta el XIX.

Además de las cuestiones históricas, a Habermas le interesan ciertos elementos normativos que dan una continuidad al proceso histórico y que son de importancia para una teoría social y política de la democracia. Su investigación histórica sobre la esfera pública moderna lo deriva a la teoría de la acción comunicativa y la democracia deliberativa.

Revista de Humanidades de Valparaíso, 2021, No 17, 63-89

(c) $(1)(9)$ CC BY-NC-ND 
La expresión del malestar en Chile: cultura, esfera pública y luchas sociales

Nicolás del Valle Orellana

La publicidad sería aquella esfera definida por el carácter público, común y abierto a la sociedad. En ella, los ciudadanos manifiestan su opinión con otros, promoviendo ciertos temas de debate público y evaluando el desempeño de la política a través de razones y argumentos. Esta sería la emergencia de la esfera pública moderna, donde la sociedad civil participa de la discusión pública. Para Habermas, esta esfera nació como una nueva institución afín a la democracia, que hace posible la opinión pública y la deliberación ciudadana.

Las críticas a la teoría de la esfera pública no tuvieron un impacto en la discusión intelectual internacional sino hasta su traducción al inglés veintisiete años después de su primera publicación. Una recopilación de estas críticas puede encontrarse en el volumen titulado Habermas y la esfera pública, compilado por Craig Calhoun (1992). En este libro, que resulta de una conferencia a propósito de la primera traducción al inglés, se reúnen artículos claves que exponen la recepción de la obra de Habermas en el pensamiento contemporáneo. Del grueso de comentarios críticos y respuestas posteriores de Habermas, es menester - al menos - destacar las que han tenido un mayor eco en las posteriores investigaciones sobre esfera pública.

En términos generales, se sostiene que el concepto de esfera pública de Habermas que tiene al consenso como su fundamento político y que asume ciertos mecanismos de exclusión social que se encuentran en el núcleo de los valores y realidades sociales que se desprenden de su estudio sobre las transformaciones estructurales en Europa. Según sus críticos, la teoría de Habermas elude la multiplicidad de luchas sociales que se despliegan con la emergencia de la esfera pública en la modernidad y no pone atención a las dinámicas de exclusión que se configuran a través del proceso de consolidación de la esfera pública burguesa. Estas exclusiones están dadas por los supuestos filosóficos de su teoría. Como señala Eley "su visión política de la democracia y la comunicación hace que Habermas olvide que la esfera pública estuvo siempre constituida por el conflicto" $(1992,306)$. En efecto, toda acción comunicativa descansa en el potencial racional del lenguaje como consenso intersubjetivo, considerando a la deliberación y la construcción de los acuerdos como las prácticas democráticas por excelencia. En cuanto a la dimensión conflictiva, Habermas concede un lugar a las luchas sociales, de hecho señala que la emergencia de la esfera pública burguesa proviene de una lucha de la burguesía contra la autoridad absolutista y tradicional. No obstante, los límites de su perspectiva teórica quedan de manifiesto al no considerar este nuevo espacio como un campo abierto de conflictos que no pueden ser reducidos solo a la lucha contra el antiguo régimen.

Siguiendo la propuesta temprana de Oskar Negt y Alexander Kluge (1973), se ha llamado la atención respecto de la influencia de las condiciones de clase en los límites de la teoría de Habermas. La esfera pública es burguesa dado que para Habermas se trata de un fenómeno de transformación estructural del orden de clase versus el orden social estamental contra el cual las modernidad se erige. Nancy Fraser (1992) ha llamado la atención respecto de espacios sociales subalternos que se constituyeron de manera para-

Revista de Humanidades de Valparaíso, 2021, No 17, 63-89 
La expresión del malestar en Chile: cultura, esfera pública y luchas sociales

Nicolás del Valle Orellana

lela contra la "publicidad burguesa" y que Negt y Kluge ya denominaban "contra-públicos". De este modo, la emergencia de este público burgués protagonista de la Ilustración es acompañado simultáneamente por "públicos subalternos", entendidos como "arenas discursivas paralelas donde los miembros de grupos sociales subordinados inventan y circulan contra-discursos para formular interpretaciones opuestas a sus identidades, intereses y necesidades" (Fraser 1992, 123). Con el surgimiento de la esfera pública burguesa también aparecieron nuevos públicos, proletarios, nacionalistas, campesinos, entre otros. Y en particular, respecto de las cuestiones de clase, la esfera pública circunscribe lo popular fuera de la publicidad burguesa. Es que la pretensión universalista de la teoría de Habermas, que entiende a la esfera pública como un espacio abierto que suspende las jerarquías de estatus, se ve cuestionada en la modernidad al ser un espacio definido por una clase social en ascenso: la burguesía.

Junto a las exclusiones sociales referentes a los componentes de clase que se presentan en la teoría de Habermas, Fraser destaca una realidad histórica no suficientemente abordada: el rol de las mujeres en los diferentes espacios que Habermas asocia a su ideal de la esfera pública. En ellos, no predomina el género masculino como suele recalcarse en la historiografía oficial; por el contrario, las versiones oficiales de la historia eluden las participaciones de las mujeres las cuales tuvieron una importancia capital en la conformación de estos espacios como clubes y salones de té donde el público burgués discutía los asuntos públicos (Rabinovitch 2001). De ahí que no se puede seguir asumiendo que la esfera pública corresponda simplemente a un ideal utópico no realizado, ya que "desde un comienzo fue también una noción ideológica masculina que funcionó para legitimar a un emergente orden de clase" (Fraser 1992, 116).

Estas exclusiones sociales — que se encuentran en la base de la teoría- pueden ser extendidas cuando se investiga respecto de las transformaciones sociales en América Latina (Juffer 2003). La configuración de una esfera pública está marcada por los procesos de democratización en toda la región, pero también respecto de la herencia colonial de las estructuras de poder y espacios políticos (Uribe-Urán 2000). El espacio abierto que encarna la esfera pública incluye también un sesgo racial que puede constatarse precisamente en otros espacios alternativos donde lo popular se configuró. La pluralidad de esferas públicas - compuestas por comunidades indígenas y afrodescendientes fuera de los espacios sociales y políticos dominados por una aristocracia de herencia o descendencia europea - enseñan que las luchas sociales democráticas resultantes de la exclusión de género, racial y de clase, se encuentran en la base de la publicidad moderna (Eley 1992; Fraser 1992; Garnham 1992; Hohendahl \& Silberman 1979; Moya 2003). La pregunta por las exclusiones que forman parte de la emergencia de la esfera pública, termina por consolidar una esfera "masculina", "burguesa" y "blanca", mostrando los límites de la democracia precisamente donde se levantan luchas feministas, obreras y raciales. La esfera pública no significaba un paréntesis a las desigualdades y jerarquías arbitrarias, sino más bien fue el advenimiento de la modernidad lo que implicó dichas exclusiones.

Revista de Humanidades de Valparaíso, 2021, No 17, 63-89 
Los aportes de Habermas son invaluables pero su categoría de esfera pública requiere de una re-configuración conceptual en miras a nuestro presente. Se trata de formular una suerte de teoría de la esfera pública donde se consideren la pluralidad de esferas públicas en la participación y formación de la opinión (Baiocchi 2003). Las críticas hacia Habermas se sustentan en un enfoque de investigación histórica que se centra en los procesos de democratización en perspectiva comparada (Koller 2010). Una vez que la esfera pública figura como el eje de la cohesión social y la legitimación política, se puede avanzar en un segundo punto: "la esfera pública indica el proceso de democratización mediante el análisis de nuevas formas de resistencias o contención política" (Clemens 2010, 374). Desde este punto de vista, el análisis del cambio político se fundamenta en el estudio de formas específicas de resistencia (Tilly 2007). No obstante, esta postura no es tan lejana a la de Habermas: la democratización es un proceso por el cual los excluidos (outsiders) devienen miembros de la comunidad política (Tilly 2002), siendo un proceso de inclusión progresivo. Así, la democratización procedería con el reforzamiento de una esfera pública cada vez más accesible.

Contrario a esta perspectiva afín a la teoría de Habermas, Calhoun argumenta lo siguiente al hablar del ideal de apertura como principio democratizador:

(...) reflejaba tanto los cierres contra el radicalismo político como el cierre sobre la base de clases. En otras palabras, fue un fracaso al cumplir con el ideal de apertura (...) que produjo la transformación estructural inicial de la esfera pública y puso en marcha una serie de luchas. $(2010,313)$

La ampliación de la esfera pública, por lo tanto, no significa una democratización paulatina, sino que más bien como una forma de exclusión para quienes no pueden ajustarse a los estándares normativos del discurso racional como una manifestación a viva voz de la composición elitista de la sociedad moderna. Esta cuestión es fundamental para comprender a la esfera pública como un campo constituido por una multiplicidad de relaciones de fuerzas, configuradas por mecanismos de exclusión y gestión de la diferencia.

Siguiendo la argumentación, la propia transformación de la esfera pública requiere de una discusión que considere las condiciones históricas. Esto termina cuestionando los supuestos teóricos racionalistas de Habermas. La apertura social y política no trajo consigo la incorporación de actores que comienzan a discutir racionalmente los asuntos comunes. Por el contrario, con la emergencia de la publicidad burguesa se desplegaron un conjunto de otras esferas públicas no-burguesas que nutrieron el repertorio político con nuevas prácticas que no necesariamente estaban orientadas al diálogo de ideas. Para Calhoun, el asunto no radica en estas prácticas no orientadas al entendimiento, sino en una distinción entre dos imágenes de una esfera pública legitimada que yace detrás de esta disputa. La de Habermas imagina un público lector compuesto por individuos privados y dispersos, donde cada lectura ocurre en la privacidad de su estudio para luego ser discutida en la 
La expresión del malestar en Chile: cultura, esfera pública y luchas sociales

Nicolás del Valle Orellana

tranquilidad de un salón de café. Por el otro lado, una imagen que considera las reuniones y asambleas en el espacio público, tanto en la calle o redes virtuales de información, que forjan una experiencia social del sufrimiento desde los conflictos.

En este segundo sentido, las opiniones no son formadas a partir de un ejercicio autónomo y privado, sino que son producidas en el calor de las discusiones públicas. Las reuniones y manifestaciones crearon una performance distintiva de la publicidad democrática, lo que llama a un concepto más amplio de la esfera pública. Las marchas y protestas se caracterizan por las estéticas de la resistencia en los muros de la ciudad y en la socialización de coreografías por medio de teléfonos móviles. De este modo, "la experiencia de encuentros en grandes grupos, pero actuando de maneras disciplinadas ayudan a constituir un sentido del pueblo como público que fue apropiado por la sociedad democrática" (Calhoun 2010, 16). Esta experiencia apunta a que la reunión de personas en el espacio público como forma de hacer política y constituir virtualmente la imagen del pueblo en la democracia contemporánea, hace de la asamblea una de las formas de hacer política en el mundo actual (Butler 2015). De acuerdo a esta perspectiva, la esfera pública un espacio democrático que facilita la configuración de una fuerza transformadora de la sociedad a través de la expresión institucional del malestar en la cultura y el sufrimiento social.

\section{El malestar en la cultura}

En su libro El malestar de la cultura (1930 [2016]), Sigmund Freud profundiza sus estudios sobre la cultura y sus implicaciones para la vida psíquica de los sujetos que comienza a desarrollar en sus trabajos durante de la década de 1920 tales como La psicología de las masas y el análisis del yo (1921) o El porvenir de una ilusión (1927 [1992]), pero que comienzan en su trabajo germinal Totem y Tabú de 1914. A propósito de las fuentes de la religión, Freud distingue dos caminos posibles para avanzar en la investigación de las religiones en las culturas humanas: la idea abstracta de un "sentimiento oceánico", que remite al sujeto a una conexión inmediata con la exterioridad del mundo (ser uno con el mundo); a la cual opone "otro camino para acercarnos a la comprensión de su pensamiento" (Freud 2016, 69). Otra manera de aproximarse a la pregunta por las fuentes de la religión es referirse más bien a su dimensión cultural constatable en las prácticas sociales y en la vida psíquica de los sujetos:

(...) a lo que el hombre común concibe su religión, al sistema de doctrinas y promisiones que, por un lado, le explican con envidiable integridad los enigmas de este mundo y, por otro lado, le aseguran que una sólida Providencia guardará su vida y recompensará en una existencia ultraterrena las eventuales privaciones que sufra en esta. (Freud 2016, 68)

La propuesta de Freud es tener un acercamiento a las fuentes de la religión desde el estudio de la cultura y la vida psíquica, cruzando la frontera disciplinar entre antropolo-

Revista de Humanidades de Valparaíso, 2021, No 17, 63-89

(c) $(1) \Theta(-)$ CC BY-NC-ND 
La expresión del malestar en Chile: cultura, esfera pública y luchas sociales

Nicolás del Valle Orellana

gía y psicología a inicios del siglo XX. Del pasaje recién citado, se puede extraer que la religión en la cultura tiene dos funciones primordiales: proveer de un esquema de pensamiento que explique claramente los misterios de la existencia, y justificar los sufrimientos acontecidos en la vida cotidiana por una salvación trascendente. Sin detenerme en ambas dimensiones, es especialmente pertinente abordar la última cuestión. La tesis del malestar de la cultura de Freud arranca desde esta deriva entre sufrimiento y cultura (o sobre cómo vivir en la cultura es vivir en el sufrimiento, o cómo la cultura nos permite lidiar con el sufrimiento producido en la cultura). La cultura proveería a la religión como una justificación al sufrimiento, subsumiéndolo en la narrativa teológica de la salvación que está por venir. Pues "tal como nos ha sido impuesta, la vida nos resulta demasiado pesada, nos depara excesivos sufrimientos, decepciones, empresas imposibles. Para soportarla no podemos pasarnos sin lenitivos ("no se puede prescindir de las muletas", nos ha dicho Theodor Fontaine)" (Freud 2016, 69). La cultura sería la muleta que nos permite lidiar psíquicamente con el sufrimiento cotidiano a través de distracciones poderosas, satisfacciones sustitutivas o narcóticas que nos hacen insensibles al padecimiento.

La ilusión que la cultura provee se ancla materialmente en el sufrimiento como mecanismo de defensa del aparato psíquico. Así, por ejemplo, el quehacer científico y artístico en la vida humana puede ser una de las más grandes distracciones que la cultura puede brindar para lidiar con el sufrimiento de la cotidianidad. De hecho, Freud da cuenta cómo técnicas específicas como el Yoga o la jardinería inciden directamente en una disposición distinta a la del malestar en la cultura (Freud 2016). La cultura brindaría las posibilidades de lidiar con el sufrimiento de distintos modos. En lo que aquí nos interesa respecto del rol del sufrimiento en la producción de un malestar en la cultura, es pertinente mencionar la distinción de Freud sobre las fuentes del sufrimiento: la supremacía de la naturaleza, la caducidad de nuestro cuerpo y las insuficiencias para coordinar las relaciones entre la familia, el Estado y la sociedad civil. Según Freud, es justamente esta última fuente del sufrimiento (la de orden social) la que no podemos soportar dado que depende de la voluntad humana y no de las condiciones trascedentes de la naturaleza: "Podemos al menos superar algunos pesares, aunque no todos; otros logramos mitigarlos, varios milenios de experiencia nos han convencido de ello. Muy distinta es nuestra actitud frente al tercer motivo de sufrimiento, el de origen social" (2016, 68-69).

El malestar social entonces, yace justamente en este punto señalado por Freud: el origen social del sufrimiento. Desde aquí, dos cuestiones: el sufrimiento emerge en la cultura, pero al mismo tiempo, todos los recursos con los que se cuentan para lidiar con el sufrimiento provienen de ella. Es claro que en Freud el malestar es resultado de una tensión entre la modernización social y el sufrimiento producido por las "aspiraciones culturales” de la vida civilizada. Y él se pregunta: “¿De qué nos sirve, por fin, una larga vida si es tan miserable, tan pobre en alegrías y rica en sufrimientos, que solo podemos saludar a la muerte como feliz liberación?" $(2016,82)$. 
La expresión del malestar en Chile: cultura, esfera pública y luchas sociales

Nicolás del Valle Orellana

En los pasajes del texto citado, se señala que el malestar es resultado del distanciamiento de la cultura respecto de la idea de felicidad, al mismo tiempo que es en y con la cultura que las sociedades han lidiado con el sufrimiento social. Para Freud el concepto de cultura "designa la suma de las producciones e instituciones que distancia nuestra vida de la de nuestros antecesores animales y que sirven a dos fines: proteger al humano contra la Naturaleza y regular las relaciones de los humanos entre sí" $(2016,83)$. Ambas cuestiones son de importancia para el argumento de este artículo, pero centrémonos por ahora en la cultura como producciones que regulan las relaciones sociales en su conjunto. La primera finalidad de la cultura para Freud es la de la autoconservación frente a las amenazas de la naturaleza, la cual debería traer consigo el dominio de ésta y la conservación de la vida humana. La cualidad biopolítica de la cultura según Freud se constata en sus pasajes dirigidos a la relación entre la higiene, la limpieza y las aspiraciones culturales de una sociedad autoreconocida como civilizada. En todos estos ejemplos, Freud se da cuenta cómo la función de la cultura está orientada a la conservación del orden social, esto es, regulando las relaciones entre los seres humanos y la naturaleza. Se sostiene que "el orden es una especie de impulso de repetición que establece, de una vez por todas, cuándo, dónde y cómo debe efectuarse determinado acto, de modo que en toda situación correspondiente nos ahorraremos las dudas e indecisiones" (Freud 2016, 86). Pero, además de esta función, se comprende también "su valoración y culto de las actividades psíquicas más superiores, de las producciones intelectuales, científicas y artísticas o por la función directriz de la vida humana que concede a las ideas" (Freud 2016, 87).

Es relevante terminar de perfilar la concepción general de la cultura como artificio que emerge desde las relaciones sociales y que tiene por función la protección de la vida humana y el ordenamiento de las relaciones entre los individuos, la familia, la sociedad, el Estado y la naturaleza. Freud enfatiza que la cultura significa restricción ahora de los propios padecimientos, porque hay un colectivo más fuerte que el individuo. Más fuerte en el sentido de la supervivencia. Pero sobre todo, hay una supresión a nivel libidinal, es decir, de los instintos por satisfacer los impulsos de placer y bienestar. Aquí se encuentra la frase: "la cultura reposa sobre la renuncia de las satisfacciones instintuales" (Freud $2016,90)$. En dicho caso, la cultura humana se erige contra la naturaleza exterior representada en las fuerzas de los elementos de la naturaleza, pero también se proyecta contra la naturaleza interior la cual Freud asocia a los últimos restos de nuestros ancestros los animales. Esta tesis, que es retomada por Adorno y Horkheimer en su célebre Dialéctica de la Ilustración (Adorno 1981), según la cual la cultura reposa en una represión, está detrás de la propuesta del malestar como categoría analítica para comprender críticamente las luchas sociales contemporáneas. Nacer en la cultura implica un sufrimiento a lo largo de todo el proceso de desarrollo de una sociedad y tiene como su correlato la frustración. "Esta frustración cultural rige el vasto dominio de las relaciones sociales entre los seres humanos, y ya sabemos que en ella reside la causa de la hostilidad opuesta a toda cultura" (Freud 2016, 90). 
La expresión del malestar en Chile: cultura, esfera pública y luchas sociales

Nicolás del Valle Orellana

Siguiendo las consideraciones hasta aquí expuestas, es factible sostener que la esfera pública figura como un espacio de aparición donde se expresa el malestar en la cultura. La tarea de la política de la cultura sería justamente lidiar con esta frustración cultural producida por la negación permanente de los propios instintos para la autoconservación. En la medida que las culturas no logran regular esta insatisfacción, el sufrimiento anclado inicialmente en los cuerpos comienza a expandirse a través de la esfera pública como un horizonte que posibilita una experiencia social del malestar. Este malestar se acumula como fuerzas que luego podrán desencadenarse social y políticamente, poniendo en cuestión la conservación del orden social en su conjunto: "Huelga decir que una cultura que deja insatisfecho a un número tan grande de sus miembros y los empuja a la revuelta no tiene perspectivas de conservarse de manera duradera ni lo merece" (Freud 1992, 12).

Para explorar esta noción del malestar como motivador de las luchas sociales en la esfera pública, profundizaremos en cómo la cultura ha logrado lidiar con este padecimiento, no distrayendo la atención - como sugiere Freud; sino expresando dicho malestar en la esfera pública y logrando cambios políticos para configurar instituciones orientadas al bienestar. En este sentido, Adorno retoma al sufrimiento social en el centro de la teoría estética, considerando que la cultura y las artes pueden expresar el sufrimiento (1970). Adorno sigue los pasos de Freud en su investigación de la cultura, articulando psicología y sociología desde la teoría crítica. Ahora bien, para Adorno, si bien la cultura tiene un carácter protésico - a propósito de la metáfora de la muleta-, en ningún caso podría reducirse a las alternativas que el propio Freud enuncia respecto de las posibilidades de la distracción y la narcosis.

\section{Cultura y sufrimiento social}

Los textos sobre teoría de la cultura de Freud son particularmente importantes para la tesis de la dialéctica de la ilustración (Del Valle 2015), pero ya venía teniendo cierta preponderancia en sus reflexiones iniciales sobre filosofia de la historia, las cuales confluyen en el texto de 1944 junto a Horkheimer. Antecedentes de esta cuestión pueden encontrarse en el ensayo La idea de la historia natural (Adorno 1932), donde se plantea una concepción materialista de la historia, que atiende al sufrimiento ocurrido en los procesos históricos de modernización de las sociedades. Esto era una cuestión central para la teoría social, dado que la filosofía de la historia informaba la teoría social. La filosofía de la historia, que tiene la idea del progreso del espíritu en el centro, yace detrás de las teorías de la modernización social. Para Adorno, aquí reside el peligro, una idea de la historia que termina por subsumir todo el sufrimiento acumulado al avance teológico del espíritu humano, considerando el padecimiento de las víctimas como una negatividad mediatizable en el curso de desarrollo del espíritu humano. De cierto modo esta también es la idea de Benjamin que se expresa en sus así popularizadas "Tesis de filosofía de la historia". El

Revista de Humanidades de Valparaíso, 2021, No 17, 63-89

(c) $(1)(9)$ CC BY-NC-ND 
La expresión del malestar en Chile: cultura, esfera pública y luchas sociales

Nicolás del Valle Orellana

materialismo histórico nos lleva a rescatar una historia del sufrimiento y esto en Adorno se enlaza con la historia subterránea del cuerpo que ha sido ocultada por la historia universal en la filosofía de la historia.

En Adorno, el sufrimiento se materializa en los cuerpos, y es en éstos donde el sufrimiento deja sus huellas. En su aforismo filosófico titulado El interés por el cuerpo, escrito junto a Horkheimer, se muestra esta lectura. En la filosofía de la historia de Hegel, el protagonista de la historia de la civilización es el espíritu y no el cuerpo, reflejando según Adorno y Horkheimer, el ocultamiento del cuerpo en la historia europea:

Por debajo de la historia conocida de Europa corre una historia subterránea. Es la historia de la suerte de los instintos y las pasiones humanas reprimidos o desfigurados por la civilización ... lo que estaba escondido surge a la luz, también la historia manifiesta y conocida aparece en su relación con aquel lado oscuro, que ha sido descuidado tanto por la leyenda oficial de los Estados nacionales como por su crítica progresista ... Afectada por la mutilación [la historia subterránea] se halla sobre todo la relación con el cuerpo (Adorno \& Horkheimer 1981, 277).

Bajo la historia universal, entonces, se fragua una historia del sufrimiento donde el cuerpo es su protagonista. Esto fue lo que junto a Walter Benjamin (1995), Adorno denominó la "historia del sufrimiento" [Leidensgeschichte]. Se trata de una historia de los cuerpos del sufrimiento y del sufrimiento de los cuerpos, pues el sufrimiento solo puede ser captado a través de su materialización en los cuerpos y también porque el cuerpo toma forma a partir del sufrimiento inflingido a lo largo de la historia. No se puede concebir esta historia oculta de la civilización occidental sin una mención a ambos.

Pero para Adorno la filosofía idealista de Hegel no corresponde solo a la prioridad del espíritu sobre el cuerpo, también se trata de la propia contraposición entre cuerpo y espíritu. Podríamos decir que el sufrimiento reside en la materialidad de los cuerpos entendida como aquello que se resiste a ser apropiado por el espíritu, aquello que no puede ser mediado por la dialéctica. Mientras que en la separación entre cuerpo y espíritu están los fundamentos del pensamiento hegeliano, para Adorno en esta separación se encuentra el peligro de la dominación ejercida en la historia de la civilización europea que Hegel lee como el progreso del espíritu. Ya la separación entre ambos significa la jerarquización de uno sobre otro. Esta es la narrativa que se repite en la historia del espíritu europeo:

Lo que les sucedió a los esclavos de la antigüedad ha sido experimentado por las víctimas hasta los modernos pueblos coloniales: han debido pasar por los peores. Había dos razas por naturaleza: los superiores y los inferiores (...) El cuerpo explotado debía ser para los inferiores lo malo, y el espíritu, al que los otros podían dedicarse, lo más alto. Este proceso ha habilitado a Europa para sus más altas creaciones culturales, pero la sospecha del engaño — que era notorio desde el principio - ha

Revista de Humanidades de Valparaíso, 2021, No 17, 63-89

(c) $(9)(9)$ CC BY-NC-ND 
La expresión del malestar en Chile: cultura, esfera pública y luchas sociales

Nicolás del Valle Orellana

reforzado, junto con el control del cuerpo, la maldad obscena, el odio-amor hacia el cuerpo, que ha impregnado el pensamiento de las masas a lo largo de los siglos. (Adorno \& Horkheimer 1981, 277)

La separación cuerpo y espíritu ha estado en la fundamentación misma del sufrimiento en la historia de la civilización europea, pues ha significado una jerarquización que justifica el ocultamiento del cuerpo en la historia por parte de las narrativas oficiales de los Estados nacionales y sus críticos. Por esta razón es que todas las "grandes creaciones culturales" ocultan dentro de sí una historia del sufrimiento. La tesis de Adorno es que los avances civilizatorios son meras máscaras de la "tácita aceptación de lo inhumano. Hay que estar conforme con el sufrimiento de los hombres: hasta su más mínima forma de contento consiste en endurecerse ante el sufrimiento" (Adorno \& Horkheimer 1981, 277). Sin embargo, la filosofía negativa de la historia de Adorno se opone a esta idea que justifica el sufrimiento y oculta la historia subterránea de los cuerpos. Esta reflexión sobre la historia afecta directamente su teoría social, donde el propio desarrollo de la sociedad supone la producción de una negatividad mediante la dominación social sobre el cuerpo y la naturaleza.

La tendencia global de la sociedad engendra hoy por doquier tendencias regresivas, es decir, personas con rasgos sádicos reprimidos. Quisiera recordar en este sentido la relación desviada y patógena con el cuerpo que Horkheimer y Adorno describen en la Dialéctica de la Ilustración. Dondequiera que la consciencia esté mutilada, pasa a ser retroproyectada de forma no libre y que es propicia a actos de violencia sobre el cuerpo y la esfera de lo corporal (Adorno \& Horkheimer 1981, 277).

La teoría crítica de Adorno se horroriza con la violencia ocurrida sobre el cuerpo al igual que lo hace el ángel de la historia en Benjamin. El sufrimiento en la historia es la motivación de la crítica. El gesto de apelar al sufrimiento comienza negando aquella imagen de unidad y continuidad hacia la libertad que se expresa en la filosofía de la historia de Hegel: "la efímera imagen de armonía con que se deleita la bondad no hace más que resaltar tanto más cruelmente en lo inconciliable el sufrimiento que imprudentemente niega" (Adorno \& Horkheimer 1981, 277). Esto último se confirma con la noción de cuerpo, pues es en él donde radica la posibilidad de denunciar la crueldad que subyace a la historia entendida como progreso del espíritu humano. El rol del sufrimiento en la filosofía de la historia de Hegel, demuestra el potencial crítico de la historia del sufrimiento de los cuerpos: "es el dolor, lo más bajo, lo corporal, lo siempre despreciado por una filosofía centrada en cuestiones espirituales, lo que puede interrumpirla y echarle en cara sus mentiras y así desautorizarla" (Adorno \& Horkheimer 1981, 277). Esta desautorización es una crítica radical a las justificaciones de las violencias ocurridas en la historia a favor del progreso. En este sentido, con la denuncia del sufrimiento, se interrumpe el discurso de la filosofía de la historia que tiene al espíritu como su motor (Adorno \& Horkheimer 1981, 277).

Revista de Humanidades de Valparaíso, 2021, No 17, 63-89

(c) $(1) \Theta(-)$ CC BY-NC-ND 
La expresión del malestar en Chile: cultura, esfera pública y luchas sociales

Nicolás del Valle Orellana

Entonces, se trata de la historia del sufrimiento de los cuerpos, de aquella historia oculta de la civilización humana. Si la filosofía de la historia de Hegel se centra en el desarrollo del espíritu, esto es, del progreso de la civilización; Adorno sostiene que toda teoría de la historia debe incluir una reflexión sobre aquella historia oculta o subterránea que no es incluida en las narrativas del progreso. Esto requerirá la justificación de una teoría que no encuentre sus fundamentos en parámetros normativos abstractos, sino que haga referencia al sufrimiento como padecimiento de los vivientes. No obstante, el sufrimiento del cuerpo se ha resistido a ser incluido en la reflexión histórica sobre la civilización (algo similar ha sucedido con la historia de Chile desde una perspectiva desarrollaste o progresista). Escuchar el sufrimiento que se encuentra tras el avance del espíritu humano en la historia es una de las disposiciones normativas de la teoría crítica de Adorno. El problema radica en que el propio sufrimiento de los cuerpos se resiste a ser conceptualizado y captado por la teoría. De ahí que se requiera un modo de pensamiento figurativo que no sea conceptual sino que vaya más allá del pensamiento representacional.

Por lo anteriormente expuesto, la teoría crítica debe ocuparse del sufrimiento y el malestar no para justificarlo, sino para expresar el sufrimiento ocurrido y no ocultarlo tras la historia de la modernización de las sociedades. Esta es una de las tareas de la filosofía y la investigación social. Desde la perspectiva de Adorno, frente a la historia de la humanidad, marcada por la dominación de la naturaleza interna y externa a los humanos, "la perpetuación del sufrimiento tiene tanto derecho a expresarse como el torturado tiene a gritar" (Adorno 1973b, 362). La tortura aparece como paradigma del sufrimiento debido a que de lo que se habla es del cuerpo. En este "expresar el sufrimiento" de los cuerpos radica lo que hasta el momento podríamos llamar su estatuto filosófico: "La necesidad de prestar la voz al sufrimiento es condición de toda verdad" (Adorno 1973b, 28). El sufrimiento, entonces, cumple un estatus teórico en tanto que toda teoría de la sociedad y la historia tendrían que prestar la voz al sufrimiento.

Contraria a la justificación del sufrimiento, la teoría de Adorno se encargaría de describir y denunciar la historia del sufrimiento en las sociedades. No obstante, este "prestar la voz" es siempre insuficiente debido a la materialidad del sufrimiento que no logra ser aprendida por los conceptos. Contra Hegel, quien pensaba en que toda negatividad pudiera ser subsumida por el espíritu absoluto, Adorno sostiene que la negatividad no logra ser mediada por la razón siendo un resto intraducible para el espíritu, "reacio al pensamiento", un algo que es incomprensible para la razón humana (1970, 32). El conocimiento racional y discursivo "puede llegar a la realidad, hasta los aspectos irracionales que brotan de su misma ley de desarrollo", pero no logra determinar al sufrimiento por medio de conceptos. Aquel pensamiento que pretende captar el sufrimiento por medio de conceptos cree que puede suavizarlo, comprenderlo, pero cuando el sufrimiento se convierte en concepto queda "mudo y estéril" (Adorno 1970, 40). Para Adorno el sufrimiento es aquello

Revista de Humanidades de Valparaíso, 2021, No 17, 63-89

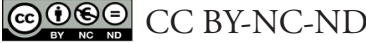


La expresión del malestar en Chile: cultura, esfera pública y luchas sociales

Nicolás del Valle Orellana

que resulta intraducible al lenguaje de las representaciones y tiene que ser expresado por una racionalidad no conceptual pues sin ello no hay una verdad respecto de la brutalidad del sufrimiento (Lemm 2009).

En esta apelación al sufrimiento de los cuerpos se encuentra una de las motivaciones políticas de la teoría crítica y la relación de la memoria cultural para con el sufrimiento, pues sólo las imágenes, sonidos y olores sobre lo ocurrido podrán redimir a las víctimas del pasado. Esta tarea de la filosofía en la historia, implicaría una relación de solidaridad con los vivientes. Respecto a este punto, a propósito de Bertolt Brecht, Adorno sostiene que el "sentimiento de solidaridad con los cuerpos (...) es inmanente a la conducta moral" (1973a, 263). La solidaridad vendría a ser ese sentimiento de expresar el sufrimiento de los otros, ese prestar la voz a los "cuerpos torturables" que Brecht mencionaba. Esto pone de relieve la conexión con algunas reflexiones de Max Horkheimer sobre la solidaridad con el sufrimiento de los seres vivientes, naturales y humanos. Esta idea que Horkheimer toma prestada de Arthur Schopenhauer aparece en el giro político que despunta la pregunta por el sufrimiento de Adorno: "la naturaleza no habría podido hacer nada más eficaz que implantar en el corazón humano ese impulso maravilloso gracias al cual el dolor del otro es sentido por uno" (Schopenhauer 2016, 780). La solidaridad con todo lo viviente es afín a la idea del carácter corporal de las experiencias objetivas del sujeto. Esta "objetividad que pesa sobre el sujeto" (Adorno 1973b, 28) despierta un sentimiento de solidaridad. En este sentido, el dolor de alguien no es algo simplemente suyo, pues afecta a todos y es parte de cierta sensibilidad común a todos los vivientes, sean humanos o no.

Nuestros cuerpos se sacuden por el dolor de los cuerpos ajenos, sentenciando que la relación con el otro no comienza desde el yo, sino desde el sufrimiento del otro, naciendo del rechazo que nos producen los cuerpos torturados y la naturaleza violentada. Según Marta Tafalla, este "sentirse afectado por el dolor de los otros, esa reacción impulsiva y corporal, es lo que Adorno denomina mímesis" (2003, 62). Esta relación de solidaridad de los humanos para con los demás seres vivientes estriba en una "naturaleza interna al ser humano y su afinidad con la naturaleza exterior que la precede" (Tafalla 2003, 62). En este punto, el concepto de mímesis en Adorno es usado para hacer referencia a una forma de expresión fuera de la esfera de las representaciones del pensamiento conceptual y que se identificaría con una forma del pensamiento estético. Las relaciones miméticas son prácticas sociales que expresan cuestiones respecto de la sociedad y la naturaleza a través de las artes y la cultura. Estas relaciones se caracterizan porque los límites entre el sí mismo y el otro se vuelven porosos y flexibles, siendo una de las bases para la solidaridad entre los humanos y la naturaleza. En este pensamiento artístico se encontrará la posibilidad de expresar el sufrimiento ocurrido en el pasado, proponiendo una alternativa a la imposibilidad de representación de la historia oculta. Para Adorno esta sensibilidad es un impulso anterior a la razón por la cual el ser humano responde a la naturaleza y se reconoce como parte de ella, es una "tendencia a perderse en el ambiente en lugar de afirmarse activamente en él, la inclinación a dejarse llevar, a recaer en la naturaleza"

Revista de Humanidades de Valparaíso, 2021, No 17, 63-89

(c) (1) @९ CC BY-NC-ND 
La expresión del malestar en Chile: cultura, esfera pública y luchas sociales

Nicolás del Valle Orellana

(Adorno \& Horkheimer 1981, 271). Esto puede ser emancipatorio en momentos donde la dominación sobre la naturaleza es implacable, pero también puede ser peligroso cuando las fuerzas no racionales se vuelven dominantes.

\section{A modo de cierre}

En el prólogo de Esfera pública de la experiencia. Análisis de la esfera pública burguesa y proletaria (Negt \& Kluge 2016), originalmente publicada en 1972 como seguimiento crítico de la obra de Habermas (1973), el teórico y cineasta Alexander Kluge junto al sociólogo Oskar Negt — ambos activos participantes de la Escuela de Fráncfort — plantean el vínculo ineludible entre la emancipación y la esfera pública. Como se señalaba en la primera sección de este artículo, la esfera pública puede ser entendida como un campo heterogéneo de relaciones de fuerza que define un horizonte para la experiencia social, siendo el espacio de despliegue de la crítica social, al mismo tiempo de ser el espacio que es disputado en tanto que condición de la experiencia. Toda práctica emancipatoria que busque lidiar con el malestar requiere de una experiencia social que permita transformar el orden establecido: "La emancipación presupone la adquisición de una experiencia. Para que la gente logre con seguridad de sí requieren no a los medios sino una esfera pública autónoma producida por ellos mismos" (Negt \& Kluge 2016, 44). Esta esfera refiere a un conjunto de:

(...) instituciones específicas, agencias, prácticas (i.e. aquellas conectada con el cumplimiento de la ley, la prensa, la opinión pública, el público, el trabajo en la esfera pública, las calles y plazas públicas); de todos modos, es también un horizonte general de la experiencia en la cual se integra todo lo que es actual u ostensiblemente relevante para todos los miembros de una sociedad (Negt \& Kluge 2016, 2)

Este horizonte general de la experiencia social opera como telón de fondo de las luchas sociales las cuales producen una esfera pública que le es propia. La lucha social tendría una función performativa respecto de la esfera pública, es decir, las prácticas de protesta y contestación producen aquel horizonte que es la esfera pública, al tiempo que ésta es la condición de posibilidad de todo ejercicio político en el espacio público. En otras palabras, la esfera pública es aquel horizonte de la experiencia social configurado por un entramado de prácticas, agentes e instituciones sometidas a su redefinición permanente por parte de las luchas sociales. Este entramado es cuestionado culturalmente en la lucha de símbolos con discursos, imágenes y cuerpos. Y dado que el sufrimiento es expresado a través de la cultura, las manifestaciones del malestar en la esfera pública que han tenido como efecto la discusión de los márgenes de lo que puede (o no) presentarse en la esfera pública, enfatizando un carácter eminentemente estético.

¿Fue el estallido social un acontecimiento emancipador? Volviendo a lo dicho en este artículo se podría sostener que significó una experiencia colectiva en la cual se reconocía

Revista de Humanidades de Valparaíso, 2021, No 17, 63-89

(c) $(1) \Theta(-)$ CC BY-NC-ND 
La expresión del malestar en Chile: cultura, esfera pública y luchas sociales

Nicolás del Valle Orellana

un malestar social cultivado durante años de sufrimiento durante el proceso de racionalización de la sociedad. Esto, a pesar de constar la inexistencia de una esfera pública común a todos quienes forman parte de la sociedad chilena. Por el contrario, se constata una pluralidad de públicos y esferas públicas que dificultan la posibilidad de coordinación entre sí. Por un lado, la emergencia de múltiples esferas publicas responde a una ampliación del campo político de las relaciones de poder y de las posibilidades de obtener una experiencia emancipadora, pero también facilita la fragmentación de una experiencia común: "Hasta hace poco todos mirábamos la misma pantalla de televisión, mientras que hoy cada cual tiene la versión del mundo que más le acomoda en las aplicaciones de su celular" (Fernández 2020, 14). A pesar de ello, el estallido social, corolario de un proceso de transformación de la sociedad chilena, desencadena la articulación entre los diferentes públicos a través de la interpelación a las subjetividades al comparecer frente a un malestar colectivo, profundo y extendido, pero ya no más difuso. El estallido social es la adquisición de una experiencia en la cual la gran parte de los miembros de la sociedad de reconocieron interpelados y participaron a través de las esferas públicas en las que participaban, haciendo uso de los medios y condiciones disponibles para la construcción de una experiencia social al protestar en el espacio público y batallar en el despliegue de discursos, imágenes y cuerpos a través de los diversos campos sociales.

La experiencia del sufrimiento como expresión del malestar tiene su correlato en políticas emancipatorias que juegan con los lenguajes artísticos y culturales. Esta cuestión es ya reconocida por Habermas cuando refiere a la esfera pública literaria y es reafirmado por Negt y Kluge: "la subjetividad que sostiene la esfera pública burguesa fue articulada a través de una matriz simbólica de la cultura, especialmente escritura, lectura y crítica literaria - actividades que desafiaban el monopolio interpretativo de la iglesia y las autoridades del Estado" $(2016,27)$. Esta esfera pública que aparece con el estallido social también se orienta por una matriz simbólica particular, la cual tiene características contrapuestas a la matriz simbólica del patrimonio y la historia oficial.

Por el contrario, esta nueva memoria cultural que comienza a fraguarse con el estallido no cuenta con liderazgos o una orgánica central, más bien se estructura en torno a imágenes de personajes ficticios con efectos políticos en la movilización o de próceres de la cultura contestataria ya fallecidos como Víctor Jara. En el estallido las calles se transformaron en galerías de arte y los muros en museos de la experiencia de la revuelta. Los sonidos de las cacerolas y antiguas canciones contestatarias vuelven a sonar. Las marchas tomaban forma con la movilización de cuerpos y discursos facilitando referentes y soportes simbólicos con los cuales articular una experiencia común de lo sucedido. Las plataformas digitales y redes virtuales hicieron su contribución con la viralización masiva de este arsenal cultural que emerge en el estallido social.

Más allá de las impresiones vertidas en los materiales revisados aquí en cuanto al estallido social, la literatura revisada indica que la esfera pública puede comprenderse como el espacio para adquirir una experiencia colectiva que exprese el malestar acumulado

Revista de Humanidades de Valparaíso, 2021, No 17, 63-89

(c) $(i) \Theta(9)$ CC BY-NC-ND 
durante años de progreso social (o en la jerga sociológica, de modernización social), esto es, que opera como un dispositivo de coordinación y comunicación de la sociedad para orientar sus procesos políticos y culturales. Si atendemos a nuestras referencias a Freud y Adorno, este malestar es en la cultura y su expresión pública es a través de prácticas artísticas y culturales que dan forma y sentido a las instituciones, prácticas y agentes que conforman la esfera pública. Esto último solo puede ser esbozado en cuanto al caso chileno. Los materiales de la protesta social y las armas de la contestación política se encuentran en aquella matriz simbólica que produce un sentido y se articula a partir de un entramado de discursos, imágenes y cuerpos. Tendremos que preguntarnos si con la emergencia de un nuevo ciclo de luchas sociales estamos presenciando un cambio cultural que reconfigure nuestra experiencia de vivir en sociedad.

\section{Referencias bibliográficas}

Adorno, T. (1932). Die Idee der Naturgeschichte. En Theodor W Adorno, Gesammelte Schriften, (pp. 345-365). Frankfurt am Main: Suhrkamp.

Adorno, T. (1970). Ästhetische Theorie. Frankfurt am Main: Suhrkamp.

Adorno, T. (1973a). Dissonanzen; Einleitung in die Musiksoziologie. Frankfurt am Main: Suhrkamp.

Adorno, T. (1973b). Negative Dialektik. Jargon der Eigentlichkeit. Frankfurt am Main: Suhrkamp.

Adorno, T. \& Horkheimer, M. (1981). Dialektik der Aufklärung. Philosophische Fragmente. Frankfurt am Main: Suhrkamp.

Atria, F., Joignant, A., Couso, J., Benavente, J. M., Larraín, Guillermo (2014). El otro modelo: del orden neoliberal al régimen de lo público. Santiago de Chile: Debate.

Baiocchi, G. (2003). Emergent Public Spheres: Talking Politics in Participatory Governance. American Sociological Review, 68(1), 52-74.

Baradit, J. (2020). Rebelión. Santiago de Chile: Sudamericana.

Benjamin, W. (1995). Sobre el concepto de historia. En P. Oyarzún (Ed.), La dialéctica en suspenso. Fragmentos sobre la historia, (pp. 45-68). Santiago de Chile: LOM.

Butler, J. (2015). Notes Toward a Performative Theory of Assembly. Cambridge, Massachussets: Harvard University Press.

Calhoun, C. (ed.) (1992). Habermas and the Public Sphere. Cambridge, Massachusetts: MIT Press.

Calhoun, C. (2010). The Public Sphere in the Field of Power. Social Science History, 34(3), 301335.

Revista de Humanidades de Valparaíso, 2021, No 17, 63-89

(c) (1) (9) CC BY-NC-ND 
Clemens, E. (2010). Democratization and Discourse: The Public Sphere and Comparative Historical Research. Social Science History, 34(3), 373-381.

Del Valle, N., Jaimovic, D., González, B., Calbucura, J., O; Maldonado, C. (2018). Conflictos sociales y ambientales en Chile. Iberoamericana, 18(67), 205-230.

Del Valle, N. (2015). Crítica de la Civilización. Sobre Dialéctica de la Ilustración en Theodor Adorno y Max Horkheimer. En N. Del Valle (ed.), La Actualidad de la Crítica. Ensayos sobre la Escuela de Frankfurt (pp. 131-171). Santiago de Chile: Editorial Metales Pesados.

Eley, G. (1992). Nations, Publics, and Political Cultures: Placing Habermas in Nineteenth Century. En C. Calhoun (ed.), Habermas and the Public Sphere (pp. 289-339). Cambridge, Massachusetts: MIT Press.

Forst, R. (2012). The right to justification: Elements of a constructivist theory of justice. New York: Columbia University Press.

Forst, R. (2015). Justificación y crítica. Buenos Aires: Katz.

Fernández, P. (2020). Sobre la marcha. Notas acerca del estallido social en Chile. Santiago de Chile: Debate.

Fraser, N. (1992). Rethinking the Public Sphere: A Contribution to the Critique of Actually Existing Democracy. En C. Calhoun (ed.), Habermas and the Public Sphere (pp. 109-142). Cambridge, Massachusetts: MIT Press.

Freud, S. (1992) [1927]. El porvenir de una ilusión. En James Strachey (ed.), Sigmund Freud. Obras Completas. El porvenir de una ilusión, El Malestar en la cultura y otras obras (1927-1931), Vol. XXI (pp. 1-55). Buenos Aires: Amorrortu.

Freud, S. (2016[1930]). El malestar en la cultura. Madrid: Biblioteca Nueva.

Garnham, N. (1992). The Media and The Public Sphere. En C. Calhoun (ed.), Habermas and the Public Sphere (pp. 357-376). Cambridge: MIT Press.

Habermas, J. (1990). Strukturwandel der Öffentlichkeit: Untersuchungen zu einer Kategorie der bürgerlichen Gesellschaft. Frankfurt am Main: Suhrkamp.

Herrera, H. (2019). Octubre en Chile. Acontecimiento y comprensión política: hacia un republicanismo popular. Santiago de Chile: Editorial Katankura.

Hohendahl, P. \& Silberman, M. (1979). Critical Theory, Public Sphere and Culture. Jürgen Habermas and His Critics. New German Critique, 16, 89-118.

Honneth, A. (2007). Pathologien der Vernunft: Geschichte und Gegenwart der Kritischen Theorie. Frankfurt am Main: Suhrkamp.

Horkheimer, M. (2010). Crítica de la razón instrumental. Madrid: Trotta.

Jaeggi, R. (2014). Alienation. New York: Columbia University Press.

Juffer, J. (2003). In Search of the Latino Public Sphere: Everywhere and Nowhere. Nepantla: Views from South, 4(2), 263-268. 


\section{La expresión del malestar en Chile: cultura, esfera pública y luchas sociales \\ Nicolás del Valle Orellana}

Kant, I. (2013). ¿Qué es la ilustración? Y otros escritos de ética, política y filosofía de la historia. Madrid: Alianza.

Koller, A. (2010). The Public Sphere and Comparative Historical Research: An Introduction. Social Science History, 34(3), 261-290. https://doi.org/10.1017/S0145553200011263

Lemm, V. (2009). Nietzsche's Animal Philosophy. Culture, Politics and the Animality of Human Being. New York: Fordham University Press.

Marx, K. (1993). Grundrisse: Foundations of the Critique of Political Economy. London: Penguin Books.

Matamala, D. (2019). La ciudad de la furia. Santiago de Chile: Catalonia.

Mayol, A. (2019). Big Bang: estallido social 2019. Santiago de Chile: Catalonia.

Morandé, P. (2017). Cultura y Modernidad en América Latina: ensayo sociológico acerca de la crisis del desarrollismo y de su superación. Santiago de Chile: IES.

Moya, P. (2003). With Us or Without Us: The Development of a Latino Public Sphere. Nepantla: Views from South, 4(2), 245-252.

Negt, O., Kluge, A. (1973). Öffentlichkeit und Erfahrung. Zur Organisationsanalyse von bürgerlicher und proletarischer Öffentlichkeit. Frankfurt am Main: Suhrkamp.

Negt, O., Kluge, A. (2016). Public Sphere and Experience. Analysis of the Bourgeois and Proletarian Public Sphere. New York/London: Verso Books.

Peña, C. (2020). Pensar el malestar. La crisis de octubre y la cuestión constitucional. Santiago de Chile: Taurus.

Rabinovitch, E. (2001). Gender and the Public Sphere: Alternative Forms of Integration in Nineteenth Century America. Sociological Theory, 19(3), 344-370.

Schopenhauer, A. (2016). Über die Grundlage der Moral. Hamburg: Felix Meiner.

Tafalla, M. (2003). Theodor W. Adorno: una filosofía de la memoria. Barcelona: Herder.

Tilly, C. (2002). Processes and Mechanisms of Democratization. Sociological Theory, 18(1), 1-16. https://doi.org/10.1111/0735-2751.00085

Tilly, C. (2007). Democracy. Cambridge: Cambridge University Press.

Uribe-Urán, V. (2000). The Birth of a Public Sphere in Latin America During the Age of Revolution. Comparative Studies in Society and History, 42(2), 425-457. 
